JIKAP PGSD: Jurnal Ilmiah Ilmu Kependidikan

Vol,3. No,1. Tahun 2019

e-ISSN: 2597-4440 dan p-ISSN: 2597-4424

This work is licensed under a Creative Commons Attribution

4.0 International License

\title{
Penerapan Metode Pembelajaran Kooperatif Tipe Number Head Together (NHT) Pada Siswa Kelas XI IPS 2 SMA Negeri 2 Watampone Untuk Meningkatkan Hasil Belajar Bahasa Indonesia
}

\author{
Jauhari \\ SMA Negeri 2 Watampone \\ Email: jauhari@gmail.com
}

\begin{abstract}
Abstrak: Tujuan penelitian ini adalah mendeskripsikan peningkatan hasil belajar bahasa Indonesia melalui metode pembelajaran kooperatif tipe Number Head Together (NHT) pada siswa Kelas XI IPS 2 SMA Negeri 2 Watampone. Pendekatan penelitian ini, yaitu deskriptif. Desain atau model penelitian ini adalah Action Research (Penelitian Tindakan kelas). Penelitian ini dilaksanakan di Kelas XI IPS 2 SMA Negeri 2 Watampone yang berjumlah 38 orang. Pengumpulan data dilakukan melalui teknik observasi, dokumentasi, dan tes. Teknik analisis data, yaitu analisis deskriptif kuantitatif dan analisis deskriptif kualitatif. Hasil penelitian menunjukkan bahwa (1) Hasil belajar siswa siklus I diktegorikan sedang dengan nilai rata-rata 64,15 dan meningkat pada siklus II menjadi kategori tinggi dengan nilai rata-rata 77,89. Ketuntasan belajar pada siklus I sebesar $44,73 \%$ dan meningkat pada siklus II menjadi $92,11 \%$. Dengan demikian, penerapan pembelajaran kooperatif NHT dapat meningkatkan hasil belajar bahasa Indonesia siswa Kelas XI IPS 2 SMA Negeri 2 Watampone. (2) Pembelajaran kooperatif NHT meningkatkan kekatifan siswa dalam belajar.
\end{abstract}

Kata kunci: hasil belajar; Pembelajaran Kooperatif; Tipe Number Head Together (NHT)

\begin{abstract}
The purpose of this study was to describe an increase in Indonesian language learning outcomes through cooperative learning methods Number Number Together (NHT) in students of Class XI IPS 2 at SMA 2 Watampone. This research approach, which is descriptive. The design or model of this research is Action Research. This research was carried out in Class XI IPS 2 of SMA Negeri 2 Watampone totaling 38 people. Data collection is done through observation, documentation, and test techniques. Data analysis techniques, namely quantitative descriptive analysis and qualitative descriptive analysis. The results showed that (1) the learning outcomes of students in the first cycle were categorized as medium with an average value of 64.15 and increased in the second cycle to be a high category with an average value of 77.89. Learning completeness in the first cycle was $44.73 \%$ and increased in the second cycle to $92.11 \%$. Thus, the application of NHT cooperative learning can improve the learning outcomes of Indonesian students in Class XI IPS 2 at SMA 2 Watampone. (2) Cooperative learning NHT increases the student's effectiveness in learning.
\end{abstract}

Keywords: Learning outcomes; Cooperative Learning; Number Head Together (NHT) Type 


\section{PENDAHULUAN}

Keberhasilan dalam proses belajar mengajar bahasa Indonesia tidak terlepas dari kesiapan peserta didik dan kesiapan pengajar. Peserta didik dituntut mempunyai minat terhadap pelajaran bahasa Indonesia demikian pula seorang guru dituntut menguasai materi yang akan diajarkan serta mampu memilih metode pembelajaran yang tepat untuk menciptakan interaksi edukatif yang baik. Seorang guru harus berupaya menciptakan suatu lingkungan belajar yang kondusif dengan cara menerapkan berbagai pendekatan, metode, dan teknik mengajar.

Pembelajaran bahasa merupakan suatu pemberian kemampuan dan keterampilan berbahasa melalui pendidikan formal mulai dari sekolah dasar hingga ke perguruan tinggi. Pembelajaran bahasa sangat kompleks, sebab diperlukan adanya guru, kurikulum, sarana dan prasarana belajar, media pembelajaran (gambar), dan evaluasi. Tujuan pembelajaran bahasa itu adalah untuk membentuk penutur bahasa yang memiliki pengetahuan, keterampilan, dan sikap positif terhadap bahasa yang digunakan (Ambo Enre dkk., 1994: 7).

Tujuan pengajaran bahasa dan sastra Indonesia berdasarkan KTSP 2006 yang lebih banyak menekankan aspek keterampilan berbahasa, masih mendapat sorotan. Sorotan demikian ini menyebabkan setiap lulusan lembaga pendidikan dipertanyakan oleh masyarakat dan giliran sorotan itu difokuskan pada insan pendidik terutama guru. Fokus sorotan didasarkan pada anggapan bahwa guru adalah orang yang paling menentukan pelaksanaan pendidikan, karena guru ujung tombak pendidikan, guru secara langsung mempengaruhi, membina, dan mengembangkan kemampuan siswa agar menjadi manusia yang cerdas, terampil, dan bermoral tinggi (Sudjana dan Arifin, 1987: 14).

Agar dapat menjalankan tugasnya dengan baik, seorang guru harus mampu menyusun sejumlah pengetahuan dan keterampilan. Guru harus berpikir mengenai cara memindahkan pengalaman dan pengetahuan tersebut kepada peserta didiknya secara efektif dan efisien, agar peserta didik tersebut dapat dengan mudah menerima dan memahami pelajaran yang diberikan kepadanya.

Salah satu masalah pokok dalam pembelajaran pada pendidikan formal dewasa ini adalah rendahnya daya serap siswa. Hal ini tampak merata hasil belajar siswa yang senantiasa masih sangat memprihatinkan. Prestasi ini tentunya merupakan hasil kondisi pembelajaran yang masih bersifat konvensional dan tidak menyentuh ranah dimensi siswa itu sendiri, yaitu bagaimana sebenarnya belajar itu (belajar untuk belajar).

Di pihak lain, secara empiris rendahnya kualitas hasil belajar siswa. Hal ini disebabkan proses pembelajaran yang didominasi oleh pembelajaran tradisional. Pada pembelajaran ini suasana kelas cendeiung bersifat teachercentered sehingga siswa menjadi pasif. Meskipun demikian, guru lebih suka menerapkan model tersebut, sebab tidak memerlukan alat dan bahan praktik, cukup menjelaskan konsep-konsep yang ada pada buku ajar atau referensi lain.

Berdasarkan hasil observasi penulis, tampak bahwa fenomena pembelajaran bahasa Indonesia, khususnya di Kelas XI IPS 2 tahun pelajaran 2012/2013 mengalami banyak masalah. Demikian halnya dengan hasil belajar studi bahasa Indonesia yang sangat rendah. Di antara 38 orang siswa masih ada $70 \%$ siswa yang memperoleh nilai 55 ke bawah. Hal ini berarti sekitar $70 \%$ orang siswa ini dinyatakan belum memenuhi standar nilai Kriteria Ketuntasan Minimal (KKM) untuk bidang studi bahasa Indonesia.

Problematika pembelajaran bahasa Indonesia tersebut, menuntut guru cerdik dan inovatif dalam memilih model pembelajaran yang menyenangkan dan cocok dengan kondisi dan minat siswa. Salah satu model pembelajaran adalah metode belajar kooperatif yang merupakan salah satu metode belajar yang dapat mengatasi problematika dalam pembelajaran. Hal ini dinyatakan karena metode belajar ini menekankan pada kerja sama yang selama ini kurang terjalin dalam pembelajaran sehingga siswa tidak memiliki sikap positif dalam pembelajaran bahasa Indonesia,

Oleh karena itu, diperlukan model yang inovatif dalam pembelajaran. Pola atau model pembelajaran yang digunakan dalam pioses pembelajan harus dapat membuat belajar bahasa Indonesia terasa mudah dan menyenangkan.

Untuk mewujudkan hal tersebut penulis berinisiatif melakukan pembelajaran melalui metode pembelajaran kooperatif tipe Number Head Together (NHT) pada Siswa Kelas XI IPS 2 SMA Negeri 2 Watampone 


\section{METODE PENELITIAN}

Penelitian ini termasuk penelitian deskriptif kualitatif yang didesain melalui penelitian tindakan kelas (class room action research) yang bertujuan mendesknpsikan peningkatan hasil belajar bahasa Indonesia melalui metode pembelajaran kooperatif tipe Number Head Together (NHT) pada siswa Kelas XI IPS 2 SMA Negeri 2 Watampone. Penelitian tindakan kelas dilaksanakan dalam bentuk kegiatan bersiklus yang terdiri atas empat tahap yaitu perencanaan, pelaksanaan tindakan, observasi, dan refleksi.

Subjek penelitian ini adalah siswa Kelas XI IPS 2 yang berjumlah 38 orang. Sebanyak 26 orang laki-laki dan 12 orang perempuan. Penelitian ini dilaksanakan di Kelas XI IPS 2 SMA Negeri 2 Watampone pada semester genap tahun pelajaran 2016/2017.

Penelitian tindakan kelas ini direncanakan sebanyak dua siklus, tiap siklus dilaksanakan sesuai perubahan yang ingin dicapai. Siklus I direncanakan 2 minggu (2 kali pertemuan) dan siklus II direncanakan 2 minggu (2 kali pertemuan).

Secara rinci pelaksanaan penelitian untuk dua siklus sebagai berikut:

1. Siklus I

a. Rancangan Perencanaan Tindakan

1) Analisis kurikulum bahasa Indonesia KTSP kelas VIII.

2) Membuat perangkat pembelajaran bahasa Indonesia, yaitu rencana pelaksanaan pembelajaran

3) Membuat lembar observasi untuk mengamati dan mengidentifikasikan segala yang terjadi selama proses belajar mengajar berlangsung.

4) Guru mempersiapkan soal berupa esai tes yang dijadikan tugas kelompok.

5) Membuat alat evaluasi untuk melihat kemampuan siswa dalam menyelesaikan soal-soal.

b. Rancangan Pelaksanaan Tindakan

1) Pada awal tatap muka, guru menjelaskan materi sesuai dengan rencana pelaksanaan pengajaran kurang lebih 10 menit.

2) Siswa diarahkan untuk membentuk kelompok-kelompok kecil yang pembagiannya menurut ukuran kemampuan yang pintar, sedang kurang disatukan dalam satu kelompok. Tiap kelompok berjumlah 5 orang.
3) Siswa diberi tugas latihan berupa soal diselesaikan secara berkelompok. Kemudian guru memanggil nomor tertentu, siswa yang nomornya disebut mengacungkan tangannya dan mencoba menjawab pertanyaan untuk seluruh kelas. Kemudian siswa diberi soal yang identik untuk diselesaikan secara perorangan.

4) Selama proses belajar mengajar berlangsung setiap kelompok tetap diawasi, dikontrol dan diarahkan serta dibimbing secara langsung pada kelompoknya yang mengalami kesulitan.

5) Lembar jawaban dari tiap kelompok dan individu diperiksa kemudian dikembalikan.

c. Rancangan Pengamatan Hasil Tindakan Observasi ini dilakukan pada saat guru melaksanakan proses belajar mengajar. Guru mencatat hal yang dialami oleh siswa dan kondisi belajar siswa berdasarkan lembar observasi yang sudah disiapkan dalam hal ini mengenai kehadiran siswa, perhatian dan keaktifan dalam mengikuti proses belajar mengajar.

d. Rancangan Refleksi

Merefleksi setiap hal yang diperoleh melalui lembar observasi. Adapun langkahlangkahnya sebagai berikut:

1) Menilai dan mengamati perkembangan hasil belajar siswa setiap kelompok serta nilai tes akhir.

2) Mengamati dan mencatat perkembangan-perkembangan yang dialami siswa pada saat belajar baik perseorangan maupun kelompok.

3) Menarik beberapa kesimpulan dari hasil analisis refleksi dan keseluruhan data yang diperoleh.

4) Memberikan kesimpulan pada siswa untuk memberi tanggapan, saran perbaikan melalui tes.

2. Siklus II

a. Rancangan Perencanaan Tindakan

1) Melanjutkan tahap perencanaan pada siklus I ke siklus II.

2) Dari hasil refleksi siklus I, guru menyusun rencana baru untuk ditindaklanjuti, atau mengawasi siswa lebih tegas lagi dan memberikan arahan dan motivasi kepada siswa yang kurang memperhatikan pelajaran atau tidak. 
3) Anggota kelompok diacak dengan tetap memperhatikan heterogenitas kelompok dan memberi motivasi siswa agar lebih bersemangat belajar Sejarah secara kelompok.

b. Rancangan Pelaksanaan Tindakan

Tindakan siklus II ini adalah melanjutkan langkah-langkah siklus I dan memperbaiki yang dianggap perlu dalam memecahkan masalah.

Tindakan yang perlu dilaksanakan adalah:

1) Melanjutkan tindakan model pembelajaran kooperatif.

2) Kelompok yang mengalami kesulitan dalam menyelesaikan tugas diberi bimbingan secara langsung dan sekali-kali diarahkan secara klasikal demikian pula halnya dengan tugas yang dikerjakan secara individu.

3) Lembar jawaban dari masing-masing kelompok dan individu dikoreksi dan dibetulkan kemudian dikembalikan untuk menjadi bahan diskusi, kemudian untuk soal-soal yang dianggap perlu penjelasan lebih lanjut, maka dibahas secara klasikal.

4) Guru memberikan pujian atau semangat baik kelompok maupun individu.

c. Rancangan Pengamatan Tindakan pada siklus I

Pada tahap ini melanjutkan kegiatan

d. Rancangan Refleksi Hasil Tindakan

Pada tahap ini umumnya langkah langkah pada siklus I dilaksanakan pada siklus II.

Instrumen yang digunakan untuk mengumpulkan data dalam rangka penelitian ini adalah:

Tabel 3.1 Tabel Frekuensi dan Persentase Nilai Siswa

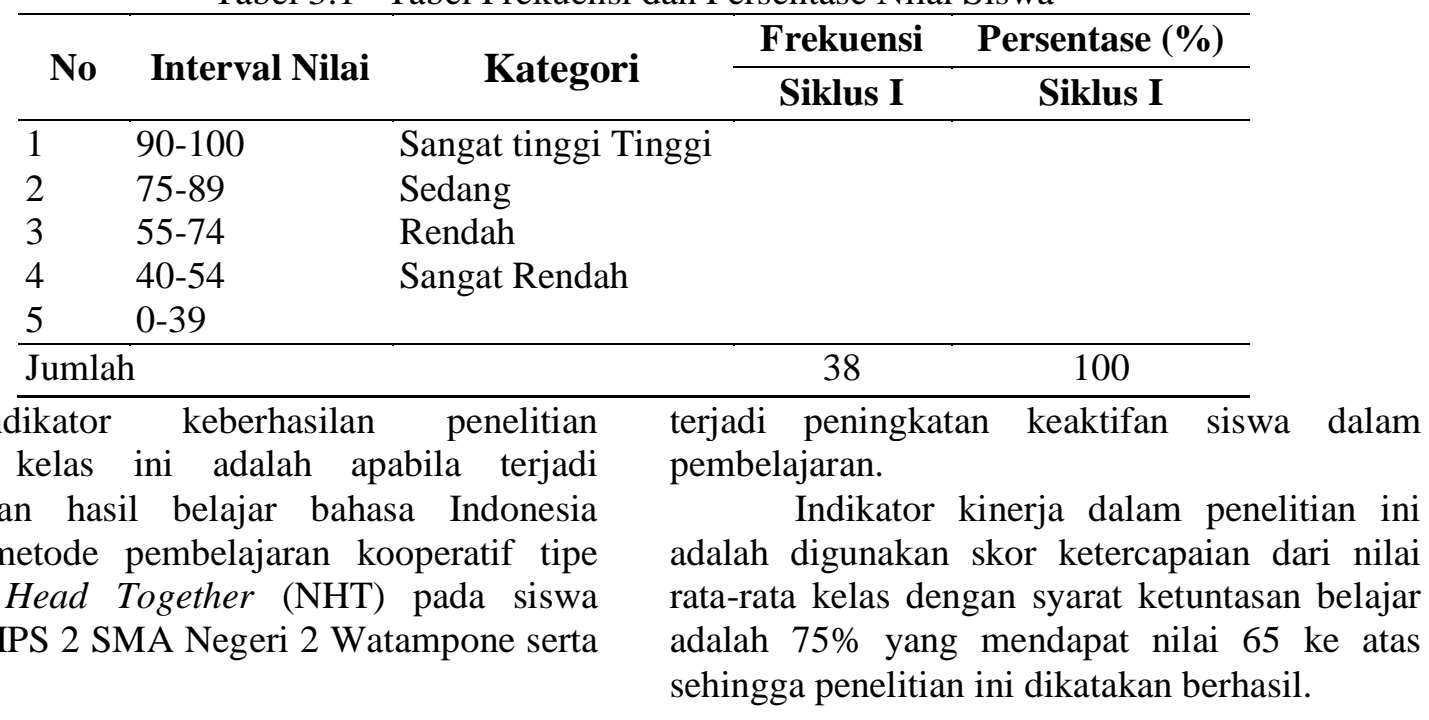




\section{HASIL DAN PEMBAHASAN}

1. Siklus I

a. Hasil Observasi

Pengamatan dilakukan dengan mengamati aktivitas siswa dengan menggunakan lembar observasi untuk mencatat kejadian-kejadian yang terjadi selama proses belajar mengajar. Hasil observasi aktivitas belajar pada siklus I ditampilkan dalam tabel berikut:

Tabel 4.1 Observasi Aktivitas Siswa pada Siklus I

\begin{tabular}{|c|c|c|c|c|c|c|}
\hline \multirow[b]{2}{*}{ No } & \multirow[b]{2}{*}{ Aktivitas siswa } & \multicolumn{5}{|c|}{ Kategori } \\
\hline & & $\begin{array}{c}\text { Sangat } \\
\text { baik }\end{array}$ & Baik & Sedang & Kurang & $\begin{array}{l}\text { Sangat } \\
\text { kurang }\end{array}$ \\
\hline 1. & $\begin{array}{l}\text { Menyimak pengarahan dan } \\
\text { penjelasan guru }\end{array}$ & & & $\sqrt{ }$ & & \\
\hline 2. & Kerjasama di kelompoknya & & & $\sqrt{ }$ & & \\
\hline 3. & Aktif berdiskusi & & & & $\sqrt{ }$ & \\
\hline 4. & Mengeluarkan pendapat & & & $\sqrt{ }$ & & \\
\hline 5. & $\begin{array}{l}\text { Mengajukan pertanyaan yang } \\
\text { relevan }\end{array}$ & & & & $\sqrt{ }$ & \\
\hline 6. & $\begin{array}{l}\text { Menjawab pertanyaan } \\
\text { dengan benar dan tepat }\end{array}$ & & & $\sqrt{ }$ & & \\
\hline
\end{tabular}

Berdasarkan tabel hasil observasi di atas maka dapat disimpulkan bahwa pada siklus I belum tampak adanya keseriusan siswa dalam mengikuti pembelajaran. Hal ini terlihat pada indikator perilaku yang tidak relevan dalam kegiatan belajar mengajar masih ada siswa yang tidak terlibat di dalam indikator tersebut. Aktivitas siswa pada siklus I belum menunjukkan adanya keseriusan dan keantusiasan siswa dalam mengikuti pembelajaran di dalam kelasnya. Hal ini terlihat pada indikator memberi tanggapan, kerjasama di kelompoknya, menjawab pertanyaan dengan benar dan tepat, dan mencatat materi.

1) Untuk indikator lainnya, yaitu mengajukan pertanyaan dan mengajukan pertanyaan yang relevan hanya sebagian siswa saja yang terlibat di dalamnya, ini disebabkan konsentrasi siswa yang belum terfokus dengan suasana belajar baru yang menuntut siswa untuk aktif bekerjasama di kelompoknya dan juga siswa belum mampu mengungkapkan pertanyaan dengan menggunakan kalimat yang tepat dan keberanian untuk menjawab pertanyaan juga masih kurang sehingga masih ada siswa kelihatan bingung dan bersikap pasif.

2) Selain itu, tingkat persentase siswa yang melakukan aktivitas lain yang tidak berkaitan dengan materi dikategorikan tinggi. Jadi, aktivitas siswa siklus I masih berada pada kategori sedang. Hal inilah yang menjadi bahan refleksi untuk pelaksanaan Siklus II. b. Hasil Evaluasi

Pembelajaran yang bertujuan menggambarkan peningkatan hasil belajar bahasa Indonesia melalui metode pembelajaran kooperatif tipe Number Head Together (NHT) pada siswa Kelas XI IPS 2 SMA Negeri 2 Watampone siklus I dilaksanakan selama dua kali pertemuan. Pada akhir pertemuan dilaksanakan tes hasil belajar yang berbentuk ulangan harian setelah selasai penyajian pokok bahasan. Dari analisis deskriptif nilai hasil belajar disajikan pada tabel 4.2 berikut:

Tabel 4.2 Statistik Nilai pada Siklus I

\begin{tabular}{l|c}
\hline \multicolumn{1}{c|}{ Statistik } & Nilai Statistik \\
\hline Subjek & Siklus I \\
\hline Nilai ideal & 38 \\
\hline Nilai tertinggi & 100 \\
\hline Nilai terendah & 80 \\
\hline Rentang nilai & 50 \\
\hline Nilai rata-rata & 50 s.d. 80 \\
\hline Modus & 64,15 \\
\hline
\end{tabular}

Berdasarkan tabel 4.2 di atas, tampak bahwa dari 38 jumlah siswa yang dites diperoleh nilai rata-rata peningkatan hasil belajar bahasa Indonesia melalui metode pembelajaran kooperatif tipe Number Head Together (NHT) pada siswa Kelas XI IPS 2 SMA Negeri 2 Watampone pada siklus I adalah sebesar 64,15. Nilai yang dicapai siswa tersebar dengan nilai tertinggi 80 dan nilai terendah 50 dari nilai 
tertinggi yang mungkin dicapai 100 dan nilai terendah yang dicapai 0 dengan rentang nilai 50 sampai dengan 80 dan modus adalah nilai 60 yang dicapai oleh 13 orang.
Apabila nilai hasil belajar siswa dikelompokkan ke dalam lima kategori, maka diperoleh distribusi frekuensi yang ditunjukkan pada tabel 4.3 berikut ini:

Tabel 4.3 Distribusi Frekuensi dan Persentase Nilai Peningkatan Hasil Belajar pada Siklus I

\begin{tabular}{lllcc}
\hline \multirow{2}{*}{ No } & \multirow{2}{*}{ Interval Nilai } & \multirow{2}{*}{ Kategori } & Frekuensi & Persentase (\%) \\
\cline { 4 - 5 } & & Siklus I & Siklus I \\
\hline 1 & $90-100$ & Sangat tinggi & 0 & 0 \\
2 & $75-89$ & Tinggi & 6 & 15.78 \\
3 & $55-74$ & Sedang & 30 & 78.94 \\
4 & $40-54$ & Rendah & 20 & 5.26 \\
5 & $0-39$ & Sangat Rendah & & 0 \\
\hline \multicolumn{2}{l}{ Jumah } & & 38 & 100 \\
\hline
\end{tabular}

Hasil analisis deskriptif di atas XI IPS 2 SMA Negeri 2 Watampone pada siklus menunjukkan bahwa hasil belajar bahasa I dan siklus II ditunjukkan pada tabel 4.4 Indonesia melalui metode pembelajaran berikut: Tabel 6. Statistik penguasan siswa pada kooperatif tipe Number Head Together (NHT) pada siswa Kelas XI IPS 2 SMA Negeri 2 Watampone siklus I dikategorikan sedang dengan nilai persentase $78,94 \%$.

Berdasarkan tabel 4.3 di atas, distribusi frekuensi, persentase, serta kategori ketercapaian ketuntasan hasil belajar bahasa Indonesia melalui metode pembelajaran kooperatif tipe Number Head Together (NHT) pada siswa Kelas tes siklus II.

Berdasarkan tabel 4.3 di atas, distribusi frekuensi, persentase, serta kategori ketercapaian ketuntasan hasil belajar bahasa Indonesia melalui metode pembelajaran kooperatif tipe Number Head Together (NHT) pada siswa Kelas XI IPS 2 SMA Negeri 2 Watampone pada siklus I dan siklus II ditunjukkan pada tabel 4.4 berikut:

Tabel 4.4 Distribusi Frekuensi. Persentase, serta Kategori Ketercapaian Ketuntasan Peningkatan Hasil Belajar pada Siklus I

\begin{tabular}{lllcc}
\hline Tes Belajar & \multicolumn{1}{c}{ Interval nilai } & Kategori & Frekuensi & Persentase (\%) \\
\hline \multirow{2}{*}{ Siklus I } & Nilai 65 ke atas & Tuntas & 17 & 44.73 \\
\cline { 2 - 5 } & Nilai di bawah 65 & Tidak tuntas & 21 & 55.26 \\
\hline & Jumlah & & 38 & 100 \\
\hline
\end{tabular}

Berdasarkan tabel 4.4 di atas, terlihat

bahwa persentase peningkatan hasil belajar bahasa Indonesia melalui metode pembelajaran kooperatif tipe Number Head Together (NHT) pada siswa Kelas XI IPS 2 SMA Negeri 2 Watampone pada siklus I sebesar $44,73 \%$ atau 17 orang dari 38 siswa berada dalam kategori tuntas dan $55,38 \%$ o atau 21 orang dari 38 siswa berada dalam kategori tidak tuntas. Hal ini berarti bahwa terdapat 21 orang dari 38 siswa yang perlu perbaikan karena belum mencapai kriteria ketuntasan individual.

Berdasarkan kriteria hasil belajar mengenai ketuntasan kelas, yaitu $>75 \%$, ata hasil pembelajaran pada siklus I di atas dianggap belum tuntas kelas di mana yang tuntas mencapai $44,73 \%$. Pembelajaran ini perlu dilanjutkan pada siklus berikutnya karena berdasarkan tujuan yang ingin dicapai, yaitu peningkatan hasil belajar belum terlihat.

\section{c. Refleksi}

Siklus I dilaksanakan dua kali pertemuan untuk peningkatan hasil belajar bahasa Indonesia melalui metode pembelajaran kooperatif tipe Number Head Together (NHT) pada siswa Kelas XI IPS 2 SMA Negeri 2 Watampone. Sebelum memasuki materi pokok. terlebih dahulu guru menyampaikan kepada siswa tujuan pembelajaran yang ingin dicapai. menciptakan suasana yang membuat siswa dapat termotivasi belajar. membentuk kelompok Number Head Together (NHT), menyajikan materi pelajaran dengan menampilkan media, membagikan bacaan kepada siswa, menugasi siswa untuk membaca materi pelajaran, mengadakan tanya jawab, memberikan tugas kepada siswa yang ada pada LKS yang telah disediakan, dan siswa ditugasi menyimpulkan materi dengan menggunakan kata-kata sendiri. Pada tahap ini, masih ada beberapa siswa yang 
kurang memperhatikan yang pada akhirnya siswa tersebut menemukan kesulitan-kesulitan pada saat mengerjakan tugas.

Pada akhir pertemuan pertama guru memberikan latihan soal mengerjakan tugas. Namun, masih banyak siswa yang tidak menyelesaikan pekerjaannya dengan berbagai alasan. Pembelajaran tahap akhir yakni memberi penghargaan kepada kelompok dan siswa yang dapat mendorong peningkatan pembelajaran. Namun, kalau dipresentasikan secara klasikal belum terlalu banyak peningkatan. Hal ini disebabkan oleh siswa belum dapat menyesuaikan secara langsung model pembelajaran yang baru diterapkan oleh guru.

Kurangnya meningkatnya hasil belajar bahasa Indonesia melalui metode pembelajaran kooperatif tipe Number Head Together (NHT) pada siswa Kelas XI IPS 2 SMA Negeri 2 Watampone pada siklus I disebabkan pula oleh bimbingan bertanya jawab yang kurang menarik, sulit menciptakan pertanyaan, kegiatan belajar mengajar kurang memberikan kesempatan kepada siswa untuk memecahkan masalah sendiri.

Kurangnya kesempatan yang diberikan kepada siswa untuk mengembangkan pengetahuannya, guru dalam mengajar kurang memahami penggunaan metode pembelajaran yang tepat dan sesuai dengan konsep yang diajarkan, guru dalam mengajar masih menggunakan metode konvesional dengan alasan cukup sederhana dan mudah dilakukan, tidak ada penggunaan media pembelajaran yang dapat membantu siswa dalam memahami suatu konsep. Berdasarkan hal ini maka tidak mengherankan jika kemudian hari diperoleh hasil belajar yang masih kurang memuaskan.

\section{Siklus II}

\section{a. Hasil Observasi}

Pengamatan aktivitas siswa digunakan pada lembar observasi untuk mencatat kejadiankejadian yang terjadi selama proses belajar mengajar. Hasil observasi aktivitas pembelajaran pada siklus II ditampilkan dalam tabel berikut:

Tabel 4.5 Observasi Aktivitas Siswa pada Siklus II

\begin{tabular}{|c|c|c|c|c|}
\hline \multirow[b]{2}{*}{ No } & \multirow[b]{2}{*}{ Aktivitas siswa } & \multicolumn{3}{|c|}{ Categori } \\
\hline & & Sangat baik Baik & Sedang $\quad$ Kurang & Sangat kurang \\
\hline 1. & $\begin{array}{l}\text { Menyimak pengarahan } \\
\text { dan penjelasan guru }\end{array}$ & $\sqrt{ }$ & & \\
\hline 2. & $\begin{array}{ll}\text { Kerjasama } & \text { di } \\
\text { kelompoknya } & \end{array}$ & $\sqrt{ }$ & & \\
\hline 3. & Aktifberdiskusi & $\sqrt{ }$ & & \\
\hline 4. & Mengeluarkan pendapat & $\sqrt{ }$ & & \\
\hline 5. & $\begin{array}{ll}\text { Mengajukan pertanyaan } \\
\text { yang relevan }\end{array}$ & $\sqrt{ }$ & & \\
\hline
\end{tabular}

Aktivitas siswa pada siklus II sudah terlihat dengan jelas adanya keseriusan dan keantusiasan siswa dalam mengikuti pelajaran. Hal ini terlihat pada beberapa indikator mengalami peningkatan frekuensi di mana hampir semua siswa ikut terlibat di dalamnya, ini disebabkan karena minat belajar siswa. Indikator yang perlu ditekankan, yaitu siswa yang keluar masuk, bermain-main, dan membicarakan hal yang tidak relevan dengan mated pelajaran berkurang drastis, sebaliknya siswa yang aktif menyimak, aktif bertanya dan menjawab pertanyaan meningkat sangat signifikan.

\section{b. Hasil Evaluasi}

Pembelajaran yang bertujuan menggambarkan peningkatan hasil belajar bahasa Indonesia melalui metode pembelajaran kooperatif tipe Number Head Together (NHT) pada siswa Kelas XI IPS 2 SMA Negeri 2 Watampone siklus II dilaksanakan selama dua kali pertemuan. Pada akhir pertemuan dilaksanakan tes hasil belajar yang berbentuk ulangan harian setelah selasai penyajian pokok bahasan. Dari analisis deskriptif nilai hasil belajar disajikan pada tabel 4.6 berikut: 
JIKAP PGSD: Jurnal Ilmiah Ilmu Kependidikan

Tabel 4.6 Statistik Nilai Siklus II

\begin{tabular}{lc}
\hline \multicolumn{1}{c}{ Statistik } & Nilai Statistik \\
\hline Subjek & Siklus II \\
\hline Nilai ideal & 38 \\
\hline Nilai tertinggi & 100 \\
\hline Nilai terendah & 95 \\
\hline Rentang nilai & 60 \\
\hline Nilai rata-rata & 60 s.d. 95 \\
\hline Modus & 77,89 \\
\hline
\end{tabular}

Berdasarkan tabel 4.6 di atas, tampak bahwa dari 38 jumlah siswa yang dites diperoleh nilai rata-rata peningkatan hasil belajar bahasa Indonesia melalui metode pembelajaran kooperatif tipe Number Head Together (NHT) pada siswa Kelas XI IPS 2 SMA Negeri 2 Watampone pada siklus sebesar 77,89. Nilai yang dicapai siswa tersebar dengan nilai tertinggi 95 dan nilai terendah 60 dari nilai tertinggi yang mungkin dicapai 100 dan nilai terendah yang dicapai 0 , dengan rentang nilai 60 sampai dengan 95 dan modus 75 yang dicapai oleh 9 orang.

Apabila nilai hasil belajar siswa dikelompokkan ke dalam lima kategori, maka diperoleh distribusi frekuensi yang ditunjukkan pada tabel 4.7 berikut ini:

Tabel 4.7 Distribusi Frekuensi dan Persentase Nilai Peningkatan Hasil Belajar pada Siklus II

\begin{tabular}{ccccc}
\hline \multirow{2}{*}{ No } & \multirow{2}{*}{ Interval Nilai } & \multirow{2}{*}{ Kategori } & Frekuensi & Persentase (\%) \\
\cline { 3 - 5 } & & Siklus II & Siklus II \\
\hline 1 & $90-100$ & Sangat tinggi & 11 & 28.94 \\
2 & $75-89$ & Tinggi & 15 & 39.47 \\
3 & $55-74$ & Sedang & 12 & 31.57 \\
4 & $40-54$ & Rendah & 0 & 0 \\
5 & $0-39$ & Sangat Rendah & 0 & 0 \\
\hline \multicolumn{5}{c}{ Jumlah } \\
\hline
\end{tabular}

Hasil analisis deskriptif di atas menunjukkan bahwa peningkatan hasil belajar bahasa Indonesia melalui metode pembelajaran kooperatif tipe Number Head Together (NHT) pada siswa Kelas XI IPS 2 SMA Negeri 2 Watampone siklus II dikategorikan sangat tinggi. Selaniutnya, pada siklus II terlihat bahwa penerapan pembelajaran kooperatif NHT berada pada kategori sangat tinggi dengan nilai persentase $39,47 \%$.

Berdasarkan tabel 4.7 di atas, distribusi frekuensi, persentase, serta kategori ketercapaian ketuntasan penerapan pembelajaran kooperatif NHT pada siklus II ditunjukkan pada tabel 4.8 berikut:

Tabel 4.8 Distribusi Frekuensi, Persentase, serta Kategori Ketercapaian Ketuntasan Peningkatan Hasil Belajar pada Siklus II

\begin{tabular}{lllcc}
\hline Tes Belajar & \multicolumn{1}{c}{ Interval nilai } & \multicolumn{1}{c}{ Kategori } & Frekuensi & Persentase (\%) \\
\hline Siklus II & Nilai 65 ke atas & Tuntas & 35 & 92,11 \\
\hline & Nilai di bawah 65 & Tidak tuntas & 3 & 7,89 \\
\hline Jumlah & & & 38 & 100 \\
\hline
\end{tabular}

Berdasarkan tabel 4.8 di atas, terlihat bahwa persentase peningkatan hasil belajar bahasa Indonesia melalui metode pembelajaran kooperatif tipe Number Head Together (NHT) pada siswa Kelas XI IPS 2 SMA Negeri 2 Watampone pada siklus II sebesar 92,11 atau 35 dari 38 siswa berada dalam kategori tuntas dan 7,89\% atau 3 siswa dari 38 orang berada pada kategori tidak tuntas. Dari siklus I sampai siklus II, hasil belajar bahasa Indonesia melalui metode pembelajaran kooperatif tipe Number Head Together (NHT) pada siswa Kelas XI IPS 2 SMA Negeri 2 Watampone mengalami peningkatan yang sangat signifikan.

Berdasarkan kriteria hasil belajar mengenai ketuntasan kelas, yaitu $>75 \%$, data hasil pembelajaran pada siklus dua di atas dianggap tuntas kelas di mana yang tuntas mencapai $92,11 \%$ dari 38 orang siswa. Pembelajaran ini tidak perlu dilanjutkan pada 
siklus berikutnya karena berdasarkan tujuan yang ingin dicapai, yaitu peningkatan hasil belajar sudah terlihat, maka penulis menganggap pembelajaran ini sudah cukup dengan menyimpulkan bahwa terjadi peningkatan hasil belajar bahasa Indonesia yang sangat signifikan melalui metode pembelajaran kooperatif tipe Number Head Together (NHT) pada siswa Kelas XI IPS 2 SMA Negeri 2 Watampone.

\section{c. Refleksi}

Siklus II dilaksanakan dua kali pertemuan dengan peningkatan hasil belajar bahasa Indonesia melalui metode pembelajaran kooperatif tipe Number Head Together pada siswa Kelas XI IPS 2 SMA Negeri 2 Watampone. Pada tahap ini, guru menyampaikan kepada siswa tujuan pembelajaran, menciptakan suasana yang membuat siswa dapat termotivasi belajar, membentuk kelompok NHT, menyajikan materi pelajaran dengan menampilkan media, menugasi siswa berdiskusi, menugasi siswa membaca cerita, memanggil nomor siswa membaca hasilnya di depan kelas, siswa ditugasi menceritakan dan menyimpulkan hasil diskusinya.

Pada kegiatan pembelajaran siklus II, kehadiran siswa $100 \%$ mengikuti pelajaran. Rasa ingin tahu dan semangatnya semakin menunjukkan peningkatan. Perhatian, motivasi, dan minat siswa dalam mengerjakan latihan yang diberikan sangat besar.

Dari hasil analisis kuantitatif dan kualitatif tampak bahwa pada dasarnya metode pembelajaran kooperatif tipe Number Head Together (NHT) pada siswa Kelas XI IPS 2 SMA Negeri 2 Watampone dapat memberikan perubahan nilai dan perilaku siswa dalam belajar. Hal ini dinyatakan sebab sebelum penerapan metode kooperatif NHT, yang diterapkan guru adalah pengajaran yang berpusat pada siswa dan ketika siswa diberi suatu masalah, mereka tidak mampu memecahkan masalah tersebut dengan usaha sendiri.

Setelah diadakan refleksi kegiatan pada siklus satu, maka dilakukan beberapa perbaikan kegiatan yang dianggap perlu demi peningkatan hasil belajar bahasa Indonesia melalui metode pembelajaran kooperatif tipe Number Head Together (NHT) pada siswa Kelas XI IPS 2 SMA Negeri 2 Watampone. Pada siklus I dan II, aktivitas dan motivasi siswa dalam belajar mengalami peningkatan. Hal ini dapat dilihat dari keaktifan siswa dalam diskusi kelompok, bertanya pada waktu pembelajaran berlangsung, keberanian dan rasa percaya diri siswa untuk mengajukan diri mengerjakan soal. Setelah diberikan tes akhir siklus dua, nilai rata-rata yang dicapai siswa berada pada kategori sangat tinggi. Dengan demikian, dapat disimpulkan bahwa hasil belajar bahasa Indonesia melalui metode pembelajaran kooperatif tipe Number Head Together (NHT) pada siswa Kelas XI IPS 2 SMA Negeri 2 Watampone meningkat.

Berdasarkan hasil penelitian penulis, pembelajaran penerapan pembelajaran kooperatif NHT dapat meningkatkan motivasi dan prestasi belajar memahami cerita. Kelompok belajar terdiri atas golongan siswa berprestasi yang tinggi dengan rendah yang dipasangkan. Masalah yang dialami oleh siswa, bukan menjadi masalah pribadi, melainkan menjadi masalah besama dan diselesaikan secara kelompok.

Perbandingan persentase ketuntasan hasil belajar bahasa Indonesia melalui metode pembelajaran kooperatif tipe Number Head Together (NHT) pada siswa Kelas XI IPS 2 SMA Negeri 2 Watampone pada siklus I sebesar $44,73 \%$ dan meningkat pada siklus II menjadi 92,11\%. Dari siklus I sampai siklus II, hasil belajar bahasa Indonesia melalui metode pembelajaran kooperatif tipe Number Head Together (NHT) pada siswa Kelas XI IPS 2 SMA Negeri 2 Watampone mengalami peningkatan yang sangat signifikan.

\section{SIMPULAN DAN SARAN}

Penyajian hasil pembelajaran dan pembahasan tentang peningkatan hasil belajar bahasa Indonesia melalui metode pembelajaran kooperatif tipe Number Head Together (NHT) pada siswa Kelas XI IPS 2 SMA Negeri 2 Watampone. Hasil pembelajaran ini menunjukkan bahwa:

1. Hasil belajar siswa siklus I diktegorikan sedang dengan nilai rata-rata 64,15 dan meningkat pada siklus II menjadi kategori tinggi dengan nilai rata-rata 77,89 . Ketuntasan belajar pada siklus I sebesar 44,73\% dan meningkat pada siklus II menjadi $92,11 \%$. Dengan demikian, penerapan pembelajaran kooperatif NHT dapat meningkatkan hasil belajar bahasa Indonesia siswa Kelas XI IPS 2 SMA Negeri 2 Watampone.

2. Pembelajaran kooperatif NHT meningkatkan kekatifan siswa dalam belajar. Indikator peningkatan tersebut dapat dicermati berdasarkan hasil belajar dari siklus I dan ke 
siklus II yang mengalami perubahan, terutama pada perubahan sikap, motivasi, antusias, dan nilai siswa belajar siswa memahami materi.

Sesuai dengan kesimpulan di atas, diajukan saran, yaitu guru hendaknya menerapkan pembelajaran kooperatif NHT karena strategi ini memotivasi siswa, menciptakan masyarakat belajar, serta dapat membantu siswa memahami materi pelajaran. Bagi siswa, hendaknya lebih meningkatkan proses dan keaktifan dalam belajar bahasa Indonesia, khususnya memahami cerita sehingga hasil yang diperoleh di masa mendatang lebih meningkat. Bagi penulis selanjutnya, diharapkan mengkaji masalah yang relevan dengan rancangan pembelajaran Tindakan Kelas (PTK) guna mengetahui lebih ilmiah tentang penerapan metode NHT dalam pembelajaran bahasa Indonesia di SMA.

\section{DAFTAR RUJUKAN}

Abdulrrahman. Pendidikan Bagi Anak Berkesulitan Belajar. Jakarta: Rineka Cipta.

Ambo Enre. Fachruddin. dkk.. 1994. Dasardasar Keterampilan Menulis. Ujnngpandang: IKIP Ujungpandang.

Depdikbud. 2005. Ramus Besar Bahasa Indonesia. Jakarta: Balai Pustaka.

Dimyati, Mudjiooo. 1993. Belajar dan Pembelajaran. Jakarta: PT Rineka Cipta.

Djamarah. Syaiful Bachri. 2000. Strategi Belajar Mengajar. Jakarta: Rineka Cipta. Dpdiknas. 2006. Standar Isi KTSP 2006 untukSD. Jakarta: Depdiknas.

Eggen, dan Kauchak. Donald P. 1996. Strategi for Teacher, Teaching Content and

Thinking Skill. Boston: Allyn dan Bocon.

Ibrahim, dkk. 2000. Pembelajaran Kooperatif. Surabaya: UNESA.

Kessler, Carolyn. 1992. Co op eratif Language Learning. A Teacher's Resource. New Jersey: A Simon dan Schurter Company.

Kunna, Wahidah. 2009) "Pemanfaatan Metode Number Heads Together (NHT) dalam Meminimalkan Kesalahan Penggunaan Kata-Kata Baku pada Karya Tulis Ilmiah Siswa Kelas VII SMA Negeri 1 Palopo." Tests. Makassar: PPS UNISMUH.

Lie, Anita, 2002. Cooperative Learning: Mempraktikkan Cooperative

Learning di Ruang-ruang Kelas. Jakarta: Gramedia Widiasarana Indonesia.
Nur, Muhammad. 2000. Pengajaran Berpusat pada Siswa dan Pendekatan Konstruktivitisme dalam Pengajaran. Surabaya: UNESA.

Pratiwi,Yuni. 2002. Strategi Belajar Kooperafif (Materi TOT CTL SLTP). Malang: Fakultas Sastra UM.

Rustam, Edi. 2008. "Peningkatan Keterampilan Berbicara Bahasa Indonesia dengan Menggunakan Strategi Belajar Kooperati Tipe NHT Siswa Kelas X SMA Negeri 5 Makassar." Tesis. Makassar: PPs UNM.

Simanjuntak dan Pasaribu. 1983. Proses Belajar Mengajar. Bandung: Tarsito.

Slameto. 1987. Belajar \& Faktor yang Mempengaruhinya. Rineka Cipta. Jakarta.

Slavin, Robert E., 2009. Cooperative Learning. Bandung: Nusa Media.

Soparno. 2002. Media Pengajaran Bahasa. Yogyakarta: PT Intan Pariwara. Sudjana, Nana. 2000. Dasar-dasar Proses Belajar Mengajar. Bandung: Sinar Baru.

Sudjana, Rifai. 1987. Media Pengajaran. Bandung: Aksara.

Sutiyorio. 2001. "Pembelajaran Koiistruktivis". Makalah yang disajikan pada Pelatihan TOT dari Enam Provinsi. 20 Juni - 6 Juli. Surabaya: Dikdasmen Depdiknas.

Tarigan, Hendry Guntur. 1985. Membaca dalam Kehidupan. Bandung: Angkasa.

Ummah, Khairul. 2003. SEPIA Kecerdasan Milyuner. Jakarta: Alia.

Wahid, Sugira. 2004. Analisis Wacana. Ujung sPandang: FPBS IKIP Ujung Pandang. 